\title{
Pengaruh Non Performing Loan dan BI Rate terhadap Return on Asset Pada Bank Umum
}

\section{The effect of non performing loan and BI rate on return on asset commercial bank}

\section{Jonathan Darmawan}

Program Studi D3 Keuangan dan Perbankan, Politeknik Negeri Bandung

E-mail: jonathan.darmawan.kepn17@polban.ac.id

\section{Banter Laksana}

Jurusan Akuntansi, Politeknik Negeri Bandung

E-mail: banter.laksana@polban.ac.id

\section{Dimas Sumitra Danisworo}

Jurusan Akuntansi, Politeknik Negeri Bandung

E-mail: dimas.danisworo@polban.ac.id

\begin{abstract}
The research aims to know the effect of Non Performing Loan (NPL) and Interest Rate of Bank Indonesia towards Return On Asset (ROA). Population in this research are listed commercial bank on Indonesia Stock Exchange (IDX) period in 2014 - 2018. The sampling of the research was performed using the method of purposive sampling. Obtained by amount sample as much 33 bank from 45 commercial banking company listed on Indonesian Stock Exchange in period 2014 - 2018. Research methodology on this research using associative method with quantitative approachment. Data analysis technique used are multi linear regression using IBM SPSS Statistic 24 for Windows software. The result of the survey encountered that partially Non Performing Loan (NPL) had a negative effects toward Return On Asset (ROA) and significant and Interest Rate of Bank Indonesia had a negative effects toward Return On Asset (ROA) and significant. Simultaneously that Non Performing Loan (NPL) and Interest Rate of Bank. Indonesia had a significant effect towards Return On Asset (ROA).
\end{abstract}

Keywords: non performing loan, BI rate, return on asset, Indonesia stock exchange

\section{Pendahuluan}

\subsection{Latar Belakang}

Pertumbuhan ekonomi 2018 tercatat 5,17\%, meningkat dibandingkan dengan pertumbuhan ekonomi tahun sebelumnya sebesar 5,07\% dan merupakan pertumbuhan tertinggi sejak 2013. Pertumbuhan ekonomi tersebut berpengaruh terhadap fungsi intermediasi perbankan, tercermin dari pertumbuhan kredit pada kredit investasi dan kredit sektor konstruksi seiring dengan berlanjutnya proyek pembangunan infrastruktur pemerintah dan proyek properti swasta. Ketahanan perbankan masih terjaga ditopang permodalan yang memadai dan meningkatnya laba (OJK, 2018).

Peningkatan laba yang diperoleh akan mempengaruhi profitabilitas. Profitabilitas perbankan menunjukan hasil kinerja yang sebagian besar berasal dari kredit yang disalurkan. Besarnya jumlah kredit yang disalurkan akan menentukan profitabilitas yang diperoleh bank (Kasmir, 2008). Kredit yang disalurkan menjadi sumber pendapatan dan keuntungan bank yang besar, disamping itu 
kredit juga merupakan jenis kegiatan pengalokasian dana bank yang sering menjadi penyebab utama suatu bank dalam menghadapi masalah besar yaitu, adanya suatu keadaan dimana nasabah sudah tidak sanggup membayar sebagian atau seluruh kewajibannya kepada bank seperti yang telah diperjanjikan, sehingga kredit tersebut bermasalah menyebabkan pula turunnya laba dan menimbulkan kerugian bagi pihak bank itu sendiri. Kredit bermasalah timbul disebabkan berbagai faktor yang berasal dari debitur, kondisi eksternal maupun kesalahan yang dilakukan oleh bank pemberi kredit (Rivai dkk, 2013). Berikut disajikan tabel besarnya penyaluran kredit, kredit bermasalah dan pendapatan bunga dari kredit yang diberikan pada Bank Umum di Indonesia..

Tabel. 1 Perkembangan Penyaluran Kredit, Kredit Bermasalah dan Pendapatan Bunga dari Kredit yang diberikan pada Bank Umum di Indonesia periode 2014-2018

(dalam miliar rupiah)

\begin{tabular}{lccc}
\hline Tahun & Penyaluran Kredit & Kredit Bermasalah & Pendapatan Bunga \\
\hline 2014 & 3.674 .308 & 79.388 & 402.163 \\
\hline 2015 & 4.057 .904 & 100.933 & 448.959 \\
\hline 2016 & 4.377 .195 & 128.135 & 472.391 \\
\hline 2017 & 4.737 .944 & 122.922 & 482.484 \\
\hline 2018 & 5.294 .882 & 125.264 & 508.391 \\
\hline
\end{tabular}

Sumber: wmw.ojk.go.id, 2018

Berdasarkan Tabel.1 penyaluran kredit pada bank umum di Indonesia mengalami kenaikkan, diikuti dengan kredit bermasalah yang meningkat disebabkan oleh risiko kredit akibat penyaluran kredit, tetapi disamping itu pendapatan bunga yang diperoleh pun semakin meningkat pula walaupun kredit bermasalahnya meningkat dalam periode 2014 - 2018.

Fungsi intermediasi perbankan juga di pengaruhi oleh faktor eksternal bank seperti perubahan kondisi makro ekonomi yang terjadi di Indonesia (Rahman, 2015) yaitu tingkat suku bunga Bank Indonesia (BI Rate) atau yang sekarang telah berubah istilah menjadi BI 7-day repo rate. Menurut Irwadi (2014:44) adanya kebijakan tingkat suku bunga yang ditetapkan oleh Bank Indonesia secara garis besar tentu akan sangat berpengaruh pada pertumbuhan yang dialami oleh perbankan di Indonesia. Kebijakan suku bunga ini tentu saja tidak terus menerus berpengaruh positif bagi perbankan, ada kalanya perbankan harus mengalami penurunan pendapatan akibat adanya kebijakan tersebut, baik itu disbabkan oleh faktor eksternal maupun internal. Berikut grafik perkembankan rata - rata suku bunga kredit, suku bunga deposito dan BI Rate. 


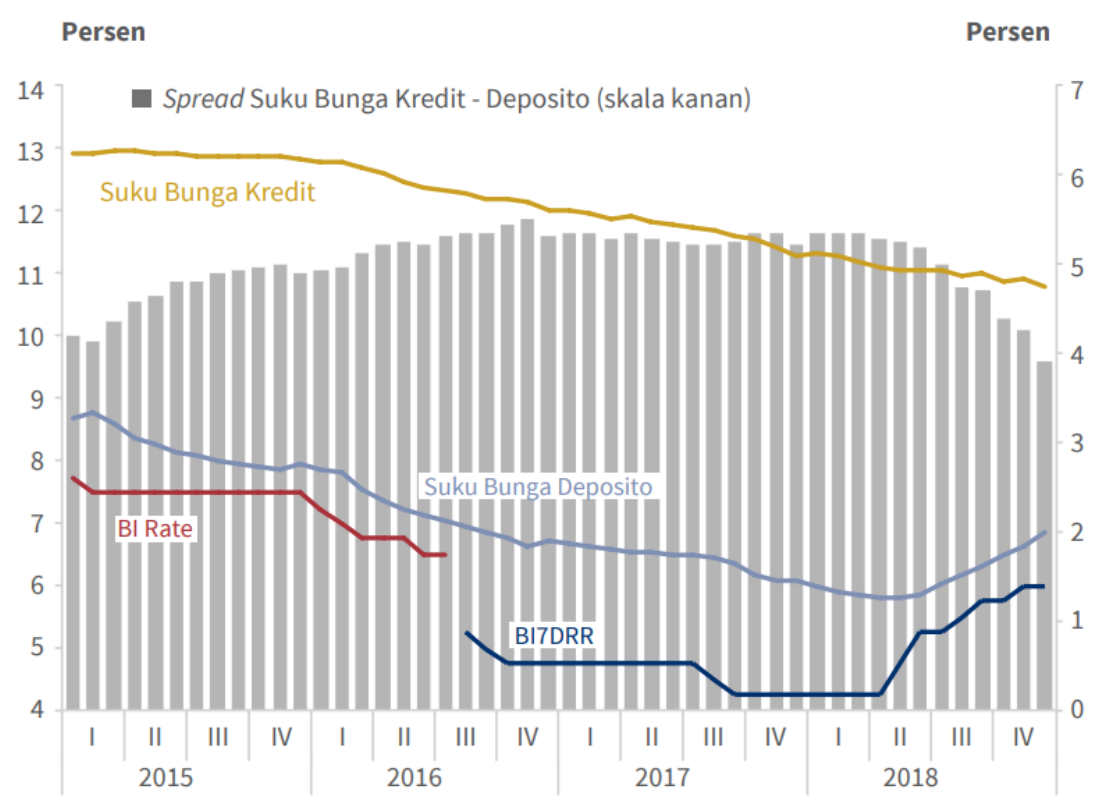

Gambar 1. Grafik Perkembangan BI Rate

Kenaikkan suku bunga juga menimbulkan perubahan dari sisi pengelolaan sumber dana dan alokasi dana (kredit). Perubahan suku bunga tersebut tentu akan berdampak pada laba yang akan diperoleh bank, bagaimana bank mengelola pendapatan bunga yang di peroleh bank dan beban bunga yang dikeluarkan bank.

Pada penelitian sebelumnya terdapat perbedaan hasil mengenai pengaruh NPL dan BI Rate terhadap ROA, penelitian yang dilakukan Ramdani (2018) menyimpulkan bahwa NPL memiliki pengaruh negatif terhadap profitabilitas (ROA) yang berarti bahwa semakin besar nilai rasio ini maka semakin kecil nilai ROA pada bank, dan BI Rate memiliki pengaruh positif terhadap profitabilitas (ROA) yang berarti bahwa kenaikan nilai BI Rate akan diikuti oleh naiknya nilai ROA. Tetapi penelitian ini tidak sejalan dengan Pangestuni dan Avitra (2016) yang mennyimpulkan bahwa NPL berpengaruh positif terhadap variabel ROA dan signifikan. Juga tidak sejalan dengan penelitian Dwijayanthy dan Naomi (2009) yang berkesimpulan bahwa BI Rate tidak berpengaruh terhdap profitabilitas bank. Dengan perbedaan hasil penelitian penelitian tersebut, maka diperlukan penelitian lebih lanjut untuk membuktian pengaruh Non Performing Loan (NPL) dan BI Rate terhadap Return On Asset (ROA).

Berdasarkan latar belakang, fenomena, dan research gap diatas, maka penulis tertarik untuk meneliti dengan judul "Pengaruh NPL dan BI Rate terhadap ROA pada Bank Umum di BEI periode 2014-2018".

\subsection{Tujuan Penelitian}

Untuk mengetahui pengaruh NPL dan BI Rate secara parsial dan simultan terhadap ROA pada Bank Umum di BEI periode 2014-2018.

\section{Kajian Pustaka}

\subsection{Non Performing Loan (NPL)}

Menurut Ismail (2010:123) Kredit bermasalah adalah semua kredit yang memiliki risiko tinggi, karena debitur telah gagal atau menghadapi masalah dalam memenuhi kewajiban yang telah ditentukan. Batas rasio NPL yang diperbolehkan Bank Indonesia maksimal 5\%, jika melebihi 5\% akan mempengaruhi penilaian tingkat kesehatan bank bersangkutan. Menurut Surat Edaran Bank Indonesia Nomor 3/30/DPNP tanggal 14 Desember 2001 besarnya NPL dihitung sebagai 
berikut:

$$
\mathrm{NPL}=\frac{\text { (Kredit Kurang Lancar }+ \text { Diragukan }+ \text { Macet })}{(\text { Total Kredit }) \times 100 \%}
$$

\subsection{BI Rate}

BI Rate adalah suku bunga dengan tenor satu bulan yang diumumkan oleh Bank Indonesia secara periodik untuk jangka waktu tertentu yang berfungsi sebagai sinyal (stance) kebijakan moneter (Siamat, 2005:139). BI Rate diumumkan oleh Dewan Gubernur Bank Indonesia setiap Rapat Dewan Gubernur bulanan dan diimplementasikan pada operasi moneter yang dilakukan Bank Indonesia melalui pengelolaan likuiditas (liquidity management) di pasar uang untuk mencapai sasaran operasional kebijakan moneter. Sasaran operasional kebijakan moneter dicerminkan pada perkembangan suku bunga Pasar Uang Antar Bank Overnight (PUAB O/N). Pergerakan di suku bunga PUAB ini diharapkan akan di ikuti oleh perkembangan di suku bunga deposito, dan pada gilirannya suku bunga kredit perbankan.

\subsection{Return On Asset (ROA)}

Menurut Dendawijaya (2009:118) Return On Assets (ROA) digunakan untuk mengukur kemampuan manajemen bank dalam memperoleh keuntungan (laba) secara keseluruhan. Semakin besar ROA suatu bank, semakin besar pula tingkat keuntungan yang dicapai bank tersebut dan semakin baik pula posisi bank tersebut dari segi penggunaan aset. Standar yang diberikan Bank Indonesia No.6/9/PBI/2004 ROA > 1,5 \% dalam kerangka penilaian kesehatan bank. Semakin besar ROA suatu bank semakin besar pula tingkat keuntungan yang dicapai bank tersebut dan semakin efisien bank tersebut dari segi penggunaan aktiva di dalam menghasilkan profit. Profitabilitas yang diproyeksikan oleh Return On Asset (ROA) dengan rumus sebagai berikut:

ROA $=\frac{\text { Laba Sebelum Pajak }}{\text { Total Aset }} \times 100 \%$

\subsection{Penelitian Terdahulu}

Ramdani (2018) dalam penelitiannya yang berjudul "Pengaruh Non Performing Loan (NPL) dan BI Rate terhadap profitabilitas (ROA) pada PT Bank QNB periode 2010 - 2017”. Metode analisis menggunakan analisis regresi linear berganda. Hasil pembahsan menemukan bahwa NPL memiliki pengaruh negatif terhadap Profitabilitas (ROA), BI Rate memiliki pengaruh positif terhadap Profitabilitas (ROA) dan keduanya berpengaruh signifikan terhadap Profitabilitas (ROA).

Qolby (2018) dalam penelitiannya yang berjudul "Pengaruh NPL dan BOPO terhadap ROA pada Bank Umum yang terdaftar di Bursa Efek Indonesia (BEI) periode 2012 - 2016". Metode analisis menggunakan analisis regresi linear berganda. Hasil pembahasan menemukan bahwa NPL berpengaruh positif terhadap ROA dan tidak signifikan, BOPO berpengaruh negatif terhadap ROA, secara simultan keduanya berpengaruh signifikan terhadap ROA.

Dwijayanthy dan Naomi (2009) dalam penelitiannya yang berjudul "Analisis pengaruh Inflasi, BI Rate, dan Nilai Tukar Mata Uang terhadap profitabilitas bank periode 2003 - 2007”. Metode analisis menggunakan analisis regresi linear berganda. Hasil pembahawan menemukan bahwa Inflasi berpengaruh negatif terhadap profitabilitas bank, BI Rate terbukti tidak berpengaruh terhadap profitabilitas bank, nilai tukar mata uang terhadap profitabilitas bank terbukti dan pengaruhnya bersifat negatif. 


\subsection{Kerangka Pemikiran}

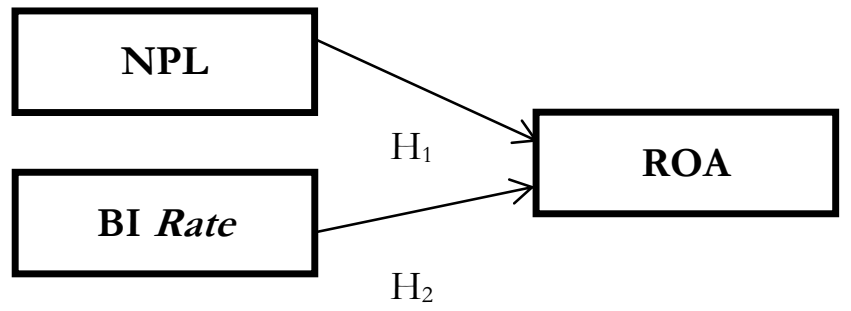

Gambar 2. Kerangka Pemikiran

\subsection{Hipotesis Penelitian}

$\mathrm{H}_{1}$ : Non Performing Loan (NPL) berpengaruh negatif terhadap Return On Asset (ROA).

$\mathrm{H}_{2}$ : BI Rate berpengaruh negatif terhadap Return On Asset (ROA).

\section{Metode Penelitian}

\subsection{Jenis Penelitian}

Penelitian yang digunakan dalam penelitian ini adalah metode penelitian asosiatif yang bertujuan untuk mengetahui hubungan antara dua variabel atau lebih antara variabel independen (X) yaitu NPL dan BI Rate dan variabel dependen (Y) yaitu ROA, dengan pendekatan kuantitatif. Jenis data yang digunakan adalah data kuantitatif dan sumber data yaitu data sekunder.

\subsection{Tempat dan Waktu Penelitian}

Penelitian ini dilakukan pada Bank Umum yang terdaftar di Bursa Efek Indonesia (BEI) periode 2014 - 2018, data sekunder diambil dari website resmi Bank Indonesia, Otoritas Jasa Keuangan dan Bursa Efek Indonesia. Waktu penelitian dilakukan bulan Maret - Agustus 2020.

\subsection{Populasi dan Sampel}

Populasi adalah wilayah generelasi yang terdiri atas objek atau subjek yang mempunyai kualitas dan karakteristik tertentu yang diterapkan oleh peneliti untuk dipelajari dan kemudian ditarik kesimpulannya (Sugiyono, 2013). Dalam penelitian in, yang menjadi populasi penelitian adalah bank umum yang terdaftar di Bursa Efek Indonesia periode 2014 sampai dengan 2018 yang berjumlah 45 bank. Menurut Sugiyono (2013), sampel adalah bagian dari jumlah dan karakteristik yang dimiliki oleh populasi tersebut. Dalam penelitian ini, teknik sampling diambil secara Purposive Sampling, yaitu teknik penentuan sampel dengan pertimbangan tertentu atau dengan kata lain dengan menggunakan kriteria tertentu yang ditetapkan oleh peneliti (Sugiyono, 2013), sampel dalam penelitian ini berjumlah 33 bank umum dari populasi yang digunakan yang terdaftar di Bursa Efek Indonesia.

\subsection{Metode Analisis}

Metode analisis data yang digunakan dalam penelitian ini adalah analisis regresi. Menurut Ghozali (2011) analisis regresi pada dasarnya adalah studi mengenai ketergantungan satu variabel dependen (terikat) dengan satu atau lebih variabel independen (bebas). Sugiyono (2013) mengemukakan bahwa analisis regresi bertujuan untuk mengetahui hubungan antara variabel independen dengan variabel dependen apakah positif atau negatif. Karena variabel bebas dalam penelitian ini menggunakan dua variabel, maka analisis regresi yang digunakan adalah regresi linier berganda dan pengolahan data pada penelitian ini menggunakan software SPSS. Berikut model persamaan regresi linier berganda :

$\mathrm{Y}=\alpha+\beta_{1} X_{1}+\beta_{2} X_{2}+\mathrm{e}$

Keterangan : $\mathrm{Y}=\mathrm{ROA} ; \alpha=$ konstanta; $\beta_{1}=$ koefisien regresi $X_{1} ; \beta_{2}=$ koefisien regresi $X_{2} ; X_{1}=$ NPL; $X_{2}=$ BI Rate; e $=$ error. 


\section{Hasil dan Pembahasan (Font: Garamound, size 13)}

\subsection{Hasil Uji Asumsi Klasik}

1. Hasil Uji Normalitas

Tabel. 2 Hasil Pengujian Normalitas dengan Kolmogorov-Smirnov One-Sample Kolmogorov-Smirnov Test

\begin{tabular}{llr}
\hline $\mathrm{N}$ & & Unstandardized Residual \\
\hline Normal Parametersa,b & Mean & 153 \\
\cline { 2 - 3 } & Std. Deviation & .0000000 \\
\hline Most Extreme Differences & Absolute & .01136616 \\
\cline { 2 - 3 } & Positive & .065 \\
\cline { 2 - 3 } & Negative & .065 \\
\hline Test Statistic & .055 \\
\hline Asymp. Sig. (2-tailed) & .065 \\
\hline a. Test distribution is Normal. \\
$\begin{array}{l}\text { b. Calculated from data. } \\
\text { c. Lilliefors Significance Correction. } \\
\text { d. This is a lower bound of the true significance. }\end{array}$
\end{tabular}

Berdasarkan Tabel. 2, dapat diketahui bahwa data yang digunakan dalam penelitian ini berdistribusi normal, ditunjukkan oleh nilai signifikansi pada Asymp. Sig. (2-tailed) sebesar $0,2>0,05$.

2. Hasil Uji Multikolinearitas

Tabel. 3 Coefficients

\begin{tabular}{|c|c|c|c|c|c|c|c|}
\hline \multirow[b]{3}{*}{ Model } & \multicolumn{4}{|c|}{ Coefficients $^{\mathrm{a}}$} & \multirow[b]{3}{*}{ Sig. } & \multirow{2}{*}{\multicolumn{2}{|c|}{ Collinearity Statistics }} \\
\hline & \multicolumn{2}{|c|}{$\begin{array}{l}\text { Unstandardized } \\
\text { Coefficients }\end{array}$} & \multirow{2}{*}{$\begin{array}{l}\text { Standardized } \\
\text { Coefficients } \\
\text { Beta } \\
\end{array}$} & \multirow[b]{2}{*}{$\mathrm{T}$} & & & \\
\hline & $\mathrm{B}$ & Error & & & & Tolerance & VIF \\
\hline 1 (Constant) & .039 & .006 & & 6.959 & .000 & & \\
\hline Non Performing Loan & -.518 & .062 & -.579 & -8.287 & .000 & .936 & 1.068 \\
\hline BI Rate & -.154 & .078 & -.139 & -1.984 & .049 & .936 & 1.068 \\
\hline
\end{tabular}

a. Dependent Variable: Return On Asset

Berdasarkan Tabel. 3, dapat diketahui bahwa nilai Tolerance yang diperoleh untuk variabel NPL dan BI Rate masing - masing sebesar 0,936 dan lebih besar dari 0,10. Nilai VIF yang diperoleh masing - masing sebesar 1,068 dan lebih kecil dari 10. Maka, dari kedua penilaian diatas dapat disimpulkan bahwa data tidak terjadi multikolinearitas terhadap data yang diuji.

3. Hasil Uji Autokorelasi

Tabel. 4 Model Summary

Model Summary ${ }^{\mathrm{b}}$

\begin{tabular}{|c|c|c|c|c|c|}
\hline \multicolumn{6}{|c|}{ Model Summary } \\
\hline Mod & $\mathrm{R}$ & $\begin{array}{c}\mathrm{R} \\
\text { Square }\end{array}$ & $\begin{array}{l}\text { Adjusted R } \\
\text { Square }\end{array}$ & $\begin{array}{l}\text { Std. Error of } \\
\text { the Estimate }\end{array}$ & $\begin{array}{l}\text { Durbin- } \\
\text { Watson }\end{array}$ \\
\hline 1 & $.560^{\mathrm{a}}$ & .314 & .305 & .0114417 & 1.798 \\
\hline
\end{tabular}


a. Predictors: (Constant), BI Rate, Non Performing Loan

b. Dependent Variable: Return On Asset

Berdasarkan Tabel. 4, hasil pengolahan data menunjukkan nilai statistik Durbin-Watson (DW) sebesar 1,798. Nilai ini kemudian dibandingkan dengan nilai $\mathrm{d}_{1} \mathrm{dan}_{\mathrm{u}} \mathrm{d}_{\mathrm{u}}$ pada tabel Durbin-Watson. Jumlah data setelah dilakukan pemotongan adalah 153 data dan jumlah variabel independen yaitu dua, maka didapatkan nilai $\mathrm{d}_{1}$ dan $\mathrm{d}_{\mathrm{u}}$ pada tabel DurbinWatson (DW) masing - masing adalah 1,7093 dan 1,7622 dengan $\alpha=0,05$. Karena nilai DW di tabel IV.5 sebesar 1,798, lebih besar dari $\mathrm{d}_{\mathrm{u}}$ dan lebih kecil dari 4- $\mathrm{d}_{\mathrm{u}}$ yaitu sebesar 2,2378 atau 1,7622<1,798<2,2378 maka dapat disimpulkan bahwa tidak terjadi autokorelasi.

4. Hasil Uji Heteroskedastisitas

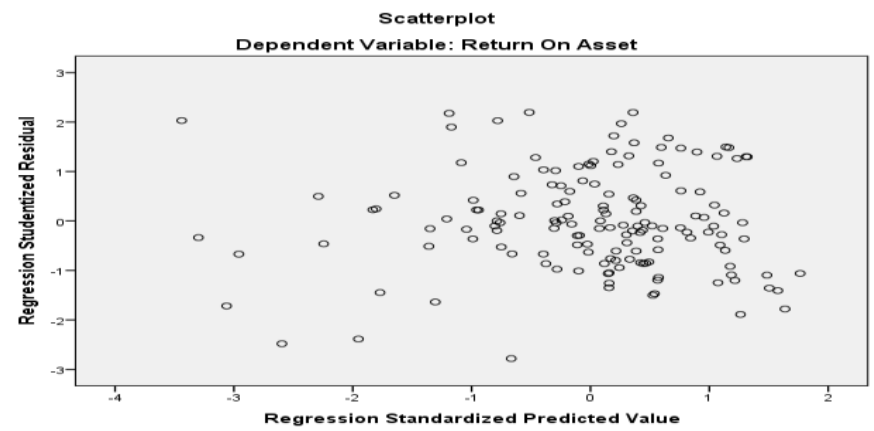

Gambar 3. Scatterplot

Berdasarkan Gambar 3. dapat diketahui bahwa data (titik - titik) menyebar secara acak diatas dan dibawah garis nol pada sumbu $\mathrm{Y}$ dan tidak membentuk pola tertentu, sehingga dapat disimpulkan bahwa data yang diuji tidak terjadi gejala heteroskedastisitas.

\subsection{Hasil Uji Parsial (Uji t)}

Dari Tabel. 3 dapat diketahui bahwa nilai Sig. NPL sebesar 0,000 dan nilai Sig, BI Rate sebesar 0,049, maka kedua variabel baik NPL maupun BI Rate berpengaruh signifikan terhadap ROA karena nilai Sig. $<0,05$. Pengaruh antara variabel independen terhadap variabel dependen secara parsial dijelaskan sebagai berikut.

Berdasarkan Tabel. 3 dapat diketahui bahwa nilai koefisien NPL menunjukkan nilai yang negatif sebesar $-0,518$, artinya terdapat pengaruh yang negatif terhadap ROA. Dan berdasarkan hasil pengujian secara spasial t hitung NPL sebesar |-8,287| > t tabel sebesar 1,975 dan nilai Sig. sebesar $0,000<0,05$, maka disimpulkan pengambilan keputusan yang dilakukan adalah $\mathrm{H}_{0}$ ditolak dan $\mathrm{H}_{1}$ diterima sehingga terdapat pengaruh negatif dan signifikan NPL terhadap ROA. Pengaruh yang negatif dan signifikan tersebut mencerminkan bahwa setiap kenaikan NPL maka akan menyebabkan menurunnya ROA.

Berdasarkan Tabel. 3 dapat diketahui bahwa nilai koefisien BI Rate menunjukkan nilai yang negatif sebesar $-0,154$, artinya terdapat pengaruh yang negatif terhadap ROA. Dan berdasarkan hasil pengujian secara spasial t hitung BI Rate sebesar $|-1,984|>\mathrm{t}$ tabel sebesar 1,975 dan nilai Sig. sebesar $0,049<0,05$, maka disimpulkan pengambilan keputusan yang dilakukan adalah $\mathrm{H}_{0}$ ditolak dan $\mathrm{H}_{1}$ diterima sehingga terdapat pengaruh negatif dan signifikan BI Rate terhadap ROA. Pengaruh yang negatif dan signifikan tersebut mencerminkan bahwa setiap kenaikan BI Rate maka akan menyebabkan menurunnya ROA. 


\subsection{Hasil Uji Simultan (Uji F)}

Tabel. 5 Anova

\section{ANOVA $^{a}$}

\begin{tabular}{lr|r|r|c|c} 
Model & Sum of Squares & df & Mean Square & F & Sig. \\
\hline 1 Regression & .009 & 2 & .004 & 34.342 & $.000^{\mathrm{b}}$ \\
\hline Residual & .020 & 150 & .000 & & \\
\hline Total & .029 & 152 & & & \\
\hline
\end{tabular}

a. Dependent Variable: Return On Asset

b. Predictors: (Constant), BI Rate, Non Performing Loan

Dari Tabel. 5 dapat diketahui bahwa nilai $\mathrm{F}$ hitung sebesar 34,342 dengan tingkat Sig. sebesar $0,000<0,05$ hal tersebut menunjukkan bahwa NPL dan BI Rate secara simultan berpengaruh signifikan terhadap ROA. Nilai $\mathrm{F}$ hitung akan dibandingkan dengan $\mathrm{F}$ tabel, didapat nilai $\mathrm{F}$ tabel dengan $\mathrm{df}_{1}=2$ dan $\mathrm{df}_{2}=150$ pada $\alpha=0,05$ adalah sebesar 3,06. Karena $\mathrm{F}$ hitung 34,342 > F tabel 3,06 dan nilai Sig. $0,000<0,05$, maka $\mathrm{H}_{1}$ dierima dan $\mathrm{H}_{0}$ ditolak, artinya terdapat pengaruh signifikan pada NPL dan BI Rate terhadap ROA pada 33 bank umum yang terdaftar di Bursa Efek Indonesia (BEI) periode 2014 - 2018. Pengaruh yang signifikan tersebut mencerminkan bahwa setiap kenaikan meupun penurunan NPL dan BI Rate akan menyebabkan menurunnya atau meningkatnya ROA.

\subsection{Pembahasan}

Dari hasil penelitian menunjukkan bahwa NPL berpengaruh negatif terhadap ROA dan signifikan. Dengan demikian hipotesis yang menyatakan bahwa NPL berpengaruh negatif terhadap ROA pada bank umum yang terdaftar di Bursa Efek Indonesia (BEI) periode 2014 2018 diterima. Artinya bahwa apabila nilai NPL naik, maka nilai ROA akan turun. Berdasarkam data bank yang ada di dalam penelitian ini, sebanyak 24 bank mengalami kenaikan NPL pada periode tahun penelitian ini yang mengakibatkan turunnya ROA secara signifikan, hal ini dikarenakan semakin tingginya penyaluran kredit dari tahun ke tahun. Sebagian besar kredit disalurkan kredit modal kerja, KPR, dan investasi. Tingginya penyaluran kredit ini disebabkan oleh beberapa faktor seperti kebutuhan nasabah, suku bunga kredit, dll. Akan tetapi penyaluran kredit yang dilakukan tidak diimbangi dengan dana pihak ketiga yang dimiliki dan cadangan kerugian yang tidak mencukupi untuk menutupi kerugian akibat kredit bermasalah, sehingga menyebabkan menurunnya profitabilitas bank yang tercermin dari ROA. Sebelas sisanya cukup baik dalam menekan angka kredit bermasalahnya sehingga ROA akan meningkat. Hasil penelitian ini sejalan dengan hasil penelitian yang dilakukan oleh Dwi Putrianingsih dan Yulianto (2016), Agustami dan Moris (2010), Maria, dkk (2017), Ramdani (2018) yang dalam penelitiannya menjelaskan bahwa NPL berpengaruh negatif terhadap profitabilitas bank. Karena ketidakmampuan nasabah dalam melaksanakan kewajibannya yang akan menimbulkan kredit yang bermasalah, karena kredit adalah aset bank dan sumber pendapatan yang besar pula maka jika kredit yang telah diberikan mengalami masalah dalam pengembaliannya, merupakan indikasi adanya masalah dalam bank tersebut yang apabila tidak segera mendapatkan solusi akan berdampak negatif bagi bank. Dan salah satu masalahnya yaitu mengurangi kemampuan bank dalam menghasilkan laba dari asetnya (ROA). Hasil penelitian ini tidak sejalan dengan penelitian yang dilakukan oleh Andanarini (2011), Qolby (2018), dan Pangestuni dan Avitra (2016) yang mengatakan bahwa NPL berpengaruh positif terhadap ROA, dikarenakan walaupun NPL naik tetapi ada beberapa faktor yang menjadikan ROA meningkat diluar faktor kredit bermasalah sehingga tidak terjadi penurunan pada ROA disaat NPL naik.

Dari hasil penelitian menunjukkan bahwa BI Rate berpengaruh negatif dan signifikan terhadap ROA. Dengan demikian hipotesis yang menyatakan bahwa BI Rate berpengaruh negatif 
terhadap ROA pada bank umum yang terdaftar di Bursa Efek Indonesia (BEI) periode 2014 2018 diterima. Artinya bahwa apabila nilai BI Rate naik, maka nilai ROA akan turun. Hal ini tidak sejalan dengan penelitian Satriyo dan Syaichu (2013), Dwijayanthy dan Naomi (2009), Nuril (2014) yang menjelaskan bahwa BI Rate tidak berpengaruh pada profitabilitas bank, sedangkan Ramdani (2018) mengungkapkan adanya pengaruh positif dan signifikan. Laju perkembangan BI Rate dari tahun 2014 - 2018 berfluktuasi dan mengalami perubahan yang cukup signifikan pula setiap tahunnya terlebih pada tahun 2015 sampai 2017 karena Bank Indonesia mengubah kebijakan BI Rate ditahun 2016 menjadi BI 7-days Repo Rate dan membuat perkembangannya menurun dengan cukup signifikan. Dengan demikian, jika bank menaikkan suku bunga mengacu pada suku bunga yang ditetapkan BI, maka minat nasabah untuk melakukan kredit yang akan menjadi keuntungan bagi bank maka profitabilitas bank (ROA) akan turun, begitu juga sebaliknya jika bank menurunkan suku bunganya maka nasabah cenderung akan melakukan kredit yang akan menjadi keuntungan bagi pihak bank dan akan menaikkan profitabilitas bank.

\section{Penutup}

\subsection{Kesimpulan}

Berdasarkan hasil pengujian dan pembahasan mengenai pengaruh Non Performing Loan (NPL) dan BI Rate terhadap Retrun On Asset (ROA) pada bank umum yang terdaftar di Bursa Efek Indonesia (BEI) periode 2014 - 2018 yang telah dikemukakan pada bab IV, dapat diambil beberapa kesimpulan sebagai berikut :

- NPL berpengaruh negatif terhadap ROA dan signifikan. Hasil ini sesuai dengan hasil penelitian yang dilakukan oleh Dwi Putrianingsih dan Yulianto (2016), Agustami dan Moris (2010), Maria, dkk (2017), Ramdani (2018) yang dalam penelitiannya mengungkapkan bahwa NPL berpengaruh negatif terhadap profitabilitas bankROA, begitupun sebaliknya menurunnya NPL akan meningkatkan ROA.

- BI Rate berpengaruh negatif terhadap ROA dan signifikan. Hal ini tidak sesuai dengan penelitian Satriyo dan Syaichu (2013), Dwijayanthy dan Naomi (2009), Nuril (2014) yang menyatakan bahwa BI Rate tidak berpengaruh pada profitabilitas bank, sedangkan Ramdani (2018) mengungkapkan adanya pengaruh positif dan signifikan.

- Secara simultan atau bersama - sama NPL dan BI Rate berpengaruh signifikan terhadap ROA.

\subsection{Saran}

Diharapkan bagi penelitian selanjutnya untuk menggunakan laporan keuangan triwulan, Bagi peneliti selanjutnya, hendaknya pada objek penelitian dapat menambahkan variabel variabel lain diluar penelitian ini baik faktor dari internal bank seperti CAR, LDR, NIM, dan eksternal bank seperti Inflasi, Nilai Tukar Rupiah dan Bagi Bank Umum yang terdaftar di Bursa Efek Indonesia diharapkan dapat menekan tingkat NPL sekecil mungkin agar dapat menaikkan ROA dan mempertahankan nilai suku bunga mengikuti kebijakan yang telah ditetapakan.

\section{Daftar Pustaka}

Kasmir. 2008. Bank Dan Lembaga Kenangan Lainnya Edisi Revisi. Jakarta: Raja Grafindo Persada.

Rivai, Veithzal dan Ella Sagala. 2013. Manajemen Sumber Daya Manusia untuk Perusahaan. Jakarta Rajawali Pers.

Rahman, M. N. 2015. “Analisis Pengaruh Dana Pibak Ketiga, BI Rate, Dan Kurs Rupiah Terbadap Profitabilitas (ROA) Pada Bank Persero Di Indonesia Pada Periode 2008 - 2014".

Irwadi, Maulan. 2014. "Pengaruh Inflasi dan BI Rate Terhadap Laba Perbankan Di Indonesia". Jurnal OCPUS. 
Ramdani, Dani. 2018. "Pengarub Non Performing Loan (NPL) Dan BI Rate Terhadap Profitabilitas (ROA) Pada PT Bank QNB Indonesia Tbk. Periode 2010 Sampai 2017”. Jurnal Politeknik Negeri Bandung.

Avitra, Risky Diba dan Pangestuni. 2016. "Analisis Pengarub CAR, NPL, LDR, NIM dan BOPO Terbadap Profotabilitas Bank”. Diponegoro Journal Of Management.

Dwijayanthy, Febrina dan Proma Naomi. 2009. "Analisis Pengarub Inflasi, BI Rate, dan Nilai Tukar Mata Uang Terhadap Profitabilitas Bank Periode 2003 - 2007”. Jurnal Universitas Paramadina.

Ismail. 2010. Manajemen Perbankan Dari Teori Menuju Aplikasi. Jakarta : Kencana.

Surat Edaran Bank Indonesia No. 3/30/DPNP tanggal 14 Desember 2001.

Siamat, Dahlan. 2005. Manajemen Lembaga Keuangan : Kebijakan Moneter dan Perbankan (Edisi Kelima). Jakarta : Lembaga Penerbit Fakultas Ekonomi Universitas Indonesia.

Dendawijaya, Lukman. 2009. Manajemen Perbankan. Jakarta : Ghalia Indonesia.

Qolby, Ismi Shofihatul. 2018. "Pengaruh NPL Dan BOPO Terbadap ROA Pada Bank Umum Yang Terdaftar Di Bursa Efek Indonesia (BEI) Periode 2012 - 2016”. Jurnal Politeknik Negeri Bandung.

Sugiyono. 2013. Metode Penelitian Kuantitatif Kualitatif Dan R\&D. Bandung. Alfabeta.

Ghozali, Imam. 2011. Aplikasi Analisis Multivariate Dengan Program SPSS. Semarang : Badan Penerbit Universitas Diponegoro.

Putrianingsih, Dwi Indah dan Arief Yulianto. 2016. "Pengaruh Non Performing Loan (NPL) dan Capital Adequacy Ratio (CAR) Terbadap Profitabilitas". Management Analysis Journal.

Agustami, Silviana dan Antoni M. W. 2010. Pengarub Non Performing Loan (NPL) Terhadap Profitabilitas" Jurnal Riset Akuntansi dan Keuangan.

Kossoh, Andreina Maria, Maryam Mangantar dan Imelda W. J. O. 2017. "Pengaruh Non Perforiming Loan (NPL), Capital Adequacy Ratio (CAR), Loan To Deposit Ratio (LDR) Terhadap Profitabilitas Pada Bank Pembangunan Daerah (BPD) Se-Indonesia Tahun 2011 - 2015”. Jurnal EMBA.

Savitri, Dhian Andanarini Minar. 2011. "Pengarub Non Performing Loan (NPL), Net Interest Margin (NIM) Dan Loan To Deposit Ratio (LDR) Terbadap Perubahan Laba Pada Bank Devisa Dan Bank Non Devisa Di Indonesia Tabun 2006 - 2010". Jurnal Ilmu Manajemen dan Akuntansi Terapan.

Wibowo, Edhi. Satriyo dan M. Syaichu. 2013. “Analisis Pengaruh Suku Bunga, Inflasi, CAR, BOPO, NPF Terhadap Profitabilitas Bank Syariab”. Diponegoro Journal Of Management.

Hidayati, Amalia Nuril 2014. "Pengarub Inflasi, BI Rate, Dan Kurs Terhadap Profitabilitas Bank Syariah Di Indonesia" 